\title{
Production of Iron-Binding Peptides from Colostral Whey by Enzymatic Hydrolysis
}

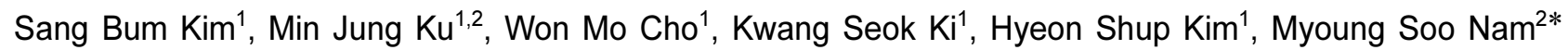 \\ ${ }^{1}$ Dairy Science Division, National Institute of Animal Science, Rural Development Administration, \\ Cheonan 330-801, Korea \\ ${ }^{2}$ Laboratory of Milk Food Biochemistry and Biotechnology, College of Agriculture and Life Sciences, \\ Chungnam National University, Daejeon 305-764, Korea
}

\begin{abstract}
Colostral whey prepared from colostrum (pooled from first six post-partum milkings) was heated for 10 min at $100^{\circ} \mathrm{C}$. Heated colostral whey was incubated with $1 \%$ enzymes (protein equivalent basis) for $15,30,60,90$, and $120 \mathrm{~min}$ at $50^{\circ} \mathrm{C}$. Papain, pepsin, trypsin, and alcalase produced different degrees of hydrolysis (DH), $10.66 \%, 12.42 \%, 10.83 \%$, and $25.31 \%$, respectively, at an incubation time of $120 \mathrm{~min}$. The SDS-PAGE reveals that significant amounts of bovine serum albumin (BSA), $\beta$-lactoglobulin ( $\beta$-LG), and $\alpha$-lactalbumin ( $\alpha$-LA) survived papain digestion. In contrast, pepsin completely removed BSA but not $\beta$-LG present in heated colostral whey. Alcalase completely eliminated BSA, $\beta$-LG, and $\alpha$-LA. This differential hydrolysis was confirmed by reversed-phase HPLC analysis. Using ion-exchange chromatography, fraction-1 (F-1) was obtained from alcalase hydrolysate at a $\mathrm{NaCl}$ gradient concentration of $0.25 \mathrm{M}$. Reversed-phase HPLC chromatograms of alcalase F-1 showed numerous small peaks, which probably indicate that a variety of new peptides were produced. Iron content of alcalase F-1 was 28.94 ppm, which was the highest among all enzyme fractions, whereas iron content of colostral whey was $36.56 \mathrm{ppm}$. Main amino acids contained in alcalase F-1 were Thr (15.45\%), Glu (14.12\%), and Ser $(10.39 \%)$. Therefore, alcalase can be used to generate good iron-binding peptides in heated colostral whey, and the resulting iron-binding peptides could be suitable as a value-added food ingredient for food supplements.
\end{abstract}

Key words: Colostral whey, hydrolysis, alcalase, iron-binding peptide

\section{Introduction}

Bovine colostrum refers to a mixture of lacteal secretions, and can be harvested immediately preceeding or following parturition. The colostrum has been known to contain serum immunoglobulins, antimicrobial peptides, and growth factors which accumulate in the mammary gland during the late pregnancy (Foley and Otterby, 1978; Playford et al., 2000).

Iron is one of the essential trace elements for human nutrition, which is obtained only through dietary intake. Iron deficiency is prevalent (WHO, 2001), due to either insufficient intake or the presence of iron absorption inhibitors. Liang et al. $(2008,2009)$ have tried different ways to decrease contents of phytic acid, which is men-

\footnotetext{
*Corresponding author: Myoung Soo Nam, Laboratory of Milk Food Biochemistry and Biotechnology, College of Agriculture and Life Sciences, Chungnam National University, Daejeon 305-764, Korea. Tel: 82-42-821-5782, Fax: 82-42-823-2766, E-mail:namsoo@cnu.ac.kr
}

tioned as an important inhibitor of iron absorption, in rice for improved bioavailability of minerals. Our previous studies (Kim et al., 2007) showed that alcalase can be used for the production of iron-binding protein/peptides from normal milk whey protein. Compared to normal milk, colostrums contains higher levels of proteins (14\%); $4.8 \%$ casein, $0.9 \%$ albumin, and $6.0 \%$ immunoglobulin (Foley and Otterby, 1978). If bovine colostrums can be used to produce iron-binding protein/peptides, more protein/peptides could be generated from colostral whey fraction than from normal whey proteins. Further, these different compositions can affect peptide production from colostral whey by enzymatic hydrolysis. This could change iron-binding capacity of protein/peptides generated from colostral whey. Therefore, it is important to study hydrolysis of colostral whey protein by various enzymes to prepare possible iron-binding protein/peptides without having antigenic protein fractions, $\beta$-lactoglobulin ( $\beta$-LG) and $\alpha$-lactalbumin ( $\alpha$-LA) (Pintado et al., 1999). The objectives of this study were to evaluate the influence of 
4 kinds of enzymes on colostral whey hydrolysis, with particular emphasis on the identification and quantification of peptides having iron-binding ability.

\section{Materials and Methods}

\section{Colostrum and enzymes}

Colostrum samples $(n=10)$ from multiparous Holstein cows were taken for first six milkings in plastic bottles on April, shipped to laboratory, and analyzed immediately with a Lactoscope (MK2; Delta Instruments, Drachten, Netherlands) that was previously standardized for colostrum. To harvest colostral whey, the frozen, pooled colostrum samples were allowed to thaw at room temperature, mixed with deionized water at a ratio of $1: 4$, and then defatted using ultracentrifugation at $12,000 \times \mathrm{g}$ for $20 \mathrm{~min}$ (Supra 25K, Hanil Sci., Incheon, Korea). Dialysis tubing cellulose membrane of $33 \times 21 \mathrm{~mm}$ size (Sigma-Aldrich, NY, USA) was used to de-mineralize the colostrum. $10 \%$ acetic acid was slowly added to de-fatted and de-mineralized colostrum samples to achieve $\mathrm{pH}$ 4.6. Acidified samples were then centrifuged at $12,000 \mathrm{~g}$ for $25 \mathrm{~min}$ for three times at $4^{\circ} \mathrm{C}$ to separate casein and colostral whey. The $\mathrm{pH}$ of the obtained colostral whey was soon raised to 7.0 with $1 \mathrm{~N} \mathrm{NaOH}$ to protect the immunoglobulins from denaturation. The whey was stored at $-80^{\circ} \mathrm{C}$ for later usage.

Alcalase EC 3.4.21.14, [Bacillus globigii (Bacillus licheniformis), activity 2.4 units/g protein], pepsin (EC 3.4.23.1, porcine gastric mucosa, activity $25,000-35,000$ units/g protein), papain (EC 3.4.22.2, Carica Papaya L., activity 14,000 units/g protein), and trypsin (EC 3.4.21.4, porcine pancreas, activity 161,000 units/g protein) were purchased from Sigma-Aldrich. Analytical grade BSA, trinitrobenzenesulfonic acid, trifluoroacetic acid (TFA; HPLC grade), and all other reagents were purchased from Sigma-Aldrich.

\section{Preparation of colostral whey hydrolysates}

The colostral whey hydrolysates were prepared from heated colostral whey according to the procedures described by Kim et al. (2007). Briefly, the frozen colostral whey was allowed to thaw at room temperature. The $\mathrm{pH}$ of colostral whey was adjusted to 8 using $0.5 \mathrm{M} \mathrm{NaOH}$ to avoid any coagulation during thermal treatment, and then the solution was heated for $10 \mathrm{~min}$ at $100^{\circ} \mathrm{C}$. The $\mathrm{pH}$ of heated colostral whey samples was adjusted using $0.5 \mathrm{M}$ $\mathrm{NaOH}$ to 8 for alcalase and trypsin, and 7.5 for papain treatments. For peptic hydrolysis the $\mathrm{pH}$ of the heated colostral whey was adjusted to 2 using $1 \mathrm{~N} \mathrm{HCl}$. The en- zymes were dissolved in deionized water to prepare a $1 \%$ solution on a protein-equivalent basis. Enzyme solutions were added to heated colostral whey samples at the ratio of 1:100 (enzyme:substrate, $\mathrm{v} / \mathrm{v}$, protein basis). The protein hydrolysis was done at $50^{\circ} \mathrm{C}$. The $\mathrm{pH}$ of each reaction mixture was further maintained at a constant level using a pH-stat technique (Metrohm Ltd., Herisau, Switzerland).

\section{Degree of hydrolysis}

For the measurement of degree of hydrolysis (DH), samples were withdrawn 15, 30, 60, 90, and 120 min after the addition of enzymes to reaction mixture. The enzymes were inactivated by heating the reaction mixture for 10 min at $90^{\circ} \mathrm{C}$, and then cooling to $-4^{\circ} \mathrm{C}$. The supernatants were taken as colostral whey hydrolysates and the precipitates were discarded. The hydrolysates were stored at $-20^{\circ} \mathrm{C}$ for subsequent estimation of $\mathrm{DH}$, peptide identification, and iron-binding capacity. The DH of colostral whey by various enzymes in the different incubation times was estimated according to Adler-Nissen (1979).

\section{SDS-PAGE}

SDS-PAGE was used to observe changes in the bands of $\alpha$-LA, $\beta$ - LG, and BSA that may be present in colostral whey hydrolysates obtained at different reaction times.

\section{Separation of iron-binding peptides}

Separation of the iron-binding peptide from the colostral whey hydrolysate was conducted by the method of Rose et al. (1969). Diethylaminoethylcellulose (DEAE; Whatman DE52, Whatman, Brentford, Middlesex, UK) was equilibrated in $500 \mathrm{~mL}$ of $20 \mathrm{mM}$ Tris- $\mathrm{HCl}$ buffer at $\mathrm{pH}$ 7.8. A slurry of equilibrated DEAE was packed in a glass column $(20 \times 2.5 \mathrm{~cm})$. Enzymatic hydrolysates were dissolved in the same buffer ( $\mathrm{pH} 7.8)$ and loaded onto the column, then eluted by a step gradient with the same buffer containing $0.25,0.5$, and $0.75 \mathrm{M} \mathrm{NaCl}$. The flow rate was $3 \mathrm{~mL} / \mathrm{min}$, the fraction volume was $30 \mathrm{~mL}$ per tube, and elutions were monitored at $280 \mathrm{~nm}$. The $40 \mathrm{~mL}$ of injection volume contained approximately $200 \mathrm{mg}$ of protein. Samples were filtered through $0.45 \mu \mathrm{m}$ membrane filters (Acrodisc Syringe Filters, Gelman Laboratory, MI, USA) prior to application to the column.

\section{Reversed-phase HPLC}

Four fractions 1 (F-1) from 4 enzymatic colostral whey hydrolysates, which was eluted at the $0.25 \mathrm{M} \mathrm{NaCl}$ gradient, were analyzed by RP-HPLC Zorbax 300SB (Agilent Technologies Inc., Palo Alto, CA, USA) $\mathrm{C}_{18}$ column (4.6 
$\times 250 \mathrm{~mm})$ equilibrated with solvent $\mathrm{A}(0.1 \%$ TFA in $\mathrm{H}_{2} \mathrm{O}$ ) and eluted with a linear hygradient of solvent $\mathrm{B}$ (0.1\% TFA in acetonitrile) for $40 \mathrm{~min}$. Runs were conducted at room temperature using an HPLC system (Agilent 1200, Agilent Technologies Inc., Palo Alto, CA, USA) at a flow rate of $1 \mathrm{~mL} / \mathrm{min}$, and the absorbance was monitored at $214 \mathrm{~nm}$. The injection volume was $10 \mathrm{~mL}$ and the concentration of protein material applied was approximately equivalent to $0.5 \mathrm{mg} / \mathrm{mL}$ of protein. All samples were filtered through $0.2 \mu \mathrm{m}$ membrane filters (Acrodisc Syringe Filters, Gelman Laboratory, MI, USA) prior to application to the $\mathrm{C}_{18}$ column.

\section{Determination of the iron-binding ability}

The heated colostral whey, its hydrolysates (supernatants), and fractions from DEAE chromatography were used to prepare $1 \%$ protein $(\mathrm{w} / \mathrm{v})$ solutions in deionized water with $\mathrm{pH}$ adjusted to 5.0. 0.1\% (w/v) $\mathrm{FeSO}_{4}$ was added to these solutions, and these mixtures were incubated for $1 \mathrm{~h}$ at $37^{\circ} \mathrm{C}$. The iron content of these mixture were determined using inductively coupled plasma (ICP) spectroscopy (ICP-OES, Varian, USA) at a wavelength of $259.94 \mathrm{~nm}$. ICP spectroscopy was operated at a radio frequency power of $1.2 \mathrm{~kW}$, coolant gas of $14 \mu \mathrm{L} / \mathrm{min}$, plasma gas of $1.2 \mu \mathrm{L} / \mathrm{min}$, and carrier gas of $0.7 \mu \mathrm{L} / \mathrm{min}$. All samples were filtered through $0.2 \mu \mathrm{m}$ membrane filters prior to their application to the ICP. The ICP standard iron (AnApex Co., Ltd., Korea) was used to make calibration curve. The iron solubility of these mixtures was calculated as an indicator of the iron-binding capacity of protein/peptides.

\section{Amino acid analysis and protein determination}

Amino acid analysis of the iron-binding protein/peptides fraction of the alcalase hydrolysate was performed by the method of Moore et al. (1958). Iron-binding protein/peptides (1 mg) were exhaustively dialyzed against distilled water and lyophilized, which was then hydrolyzed in $1 \mathrm{~mL}$ of $6 \mathrm{M} \mathrm{HCl}$ in evacuated tubes for $24 \mathrm{~h}$ at $110^{\circ} \mathrm{C}$. After speed-vacuum concentration (Mivac concentrator Range, Genevac Limited, Suffolk, UK), the sample was dissolved in $0.2 \mathrm{M}$ sodium citrate loading buffer ( $\mathrm{pH}$ 2.2), and filtered through $0.2 \mathrm{~mm}$ membrane filters. Amino acid determination was carried out on an amino acid analyzer (Biochem 20, Pharmacia, Uppsala, Sweden). Protein concentrations in the enzyme preparations, hydrolysates, and fractions were determined by the dye-binding method of Bradford (1976). Bovine serum albumin (Sigma-Aldrich, NY, USA) was used as the stan- dard. Data on DH of colostral whey hydrolysates, and iron contents of the hydrolysate fractions are presented as mean \pm SD.

\section{Statistical analysis}

Data on DH of colostral whey hydrolysates, iron contents of the hydrolysate fractions and amino acid composition of heated colostral whey and fraction 1 (F-1) are analysized by the SAS package (SAS, 2002).

\section{Results and Discussion}

\section{Protein hydrolysis}

Mean DH $( \pm \mathrm{SD})$ of heated colostral whey by 4 enzymes (Fig. 1) ranged from $5.67 \%$ to $25.31 \%$. Extensive hydrolysis of heated colostral whey was observed during the first 15 min of enzymatic treatment, followed by a slow increase in hydrolysis with increasing reaction time. Alcalase showed the highest DH of heated colostral whey compared with other enzymes at all reaction times. The respective DHs of heated colostral whey with these enzymes at 120 min were $25.31 \%$ (alcalase), $12.42 \%$ (pepsin), $10.66 \%$ (papain), and $10.83 \%$ (trypsin). These DHs were much higher than those for whey protein concentrate where DHs of whey protein concentrate were $13 \%$ (alcalase), 8\% (pepsin), 7\% (papain), and 9\% (trypsin) (Kim et al., 2007). This could be due to more substrates present in colostral whey than in whey protein concentrate. More extensive hydrolysis of whey protein with alcalase than other enzymes used in our study has been demonstrated previously by Smyth and Fitz-Gerald (1998) and Kim et al. (2007). Alcalase has been widely used to prepare soluble hydrolysates of soy protein (Fox, 1989), fish protein (Rebeca et al., 1991), and whey protein (Kim et al., 2007). As alcalase is relatively crude bacterial

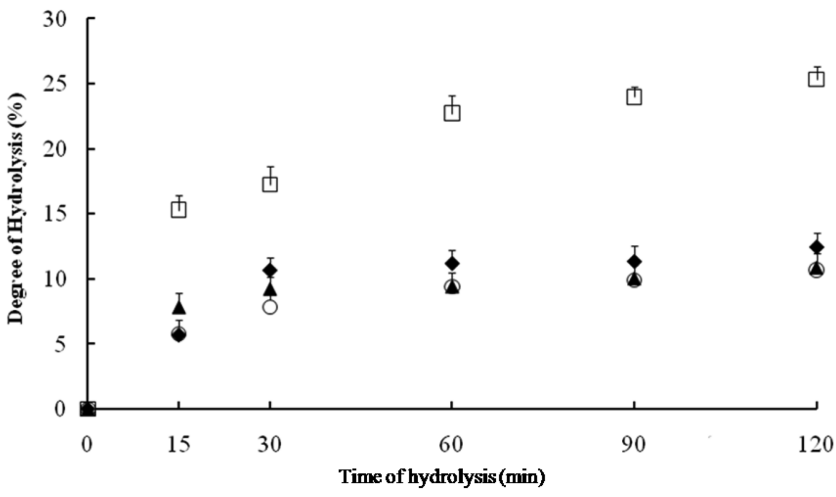

Fig. 1. Effects of alcalase $(\square)$, pepsin $(\diamond)$, typsin $(\triangle)$, and papain $(O)$ on the degree of hydrolysis of heated colostral whey at $50^{\circ} \mathrm{C}$. 
extract of B. licheniformis (Sukan and Andrews, 1982), it contains several different proteinases, each with different specificities. This property of alcalase could result in a significantly higher DH of heated colostral whey compared with enzymes such as pepsin, trypsin, or papain.

The SDS-PAGE patterns of colostral whey protein hydrolysates obtained for 120 min's incubation by enzymes are shown in Fig. 2. Alcalase (Fig. 2A) successfully hydrolyzed all the major protein fractions of colostral whey protein. Pepsin (Fig. 2B) did not completely digest $\alpha$-LA and $\beta$-LG present in colostral whey. Treatment of colostral whey by papain (Fig. 2C) and trypsin
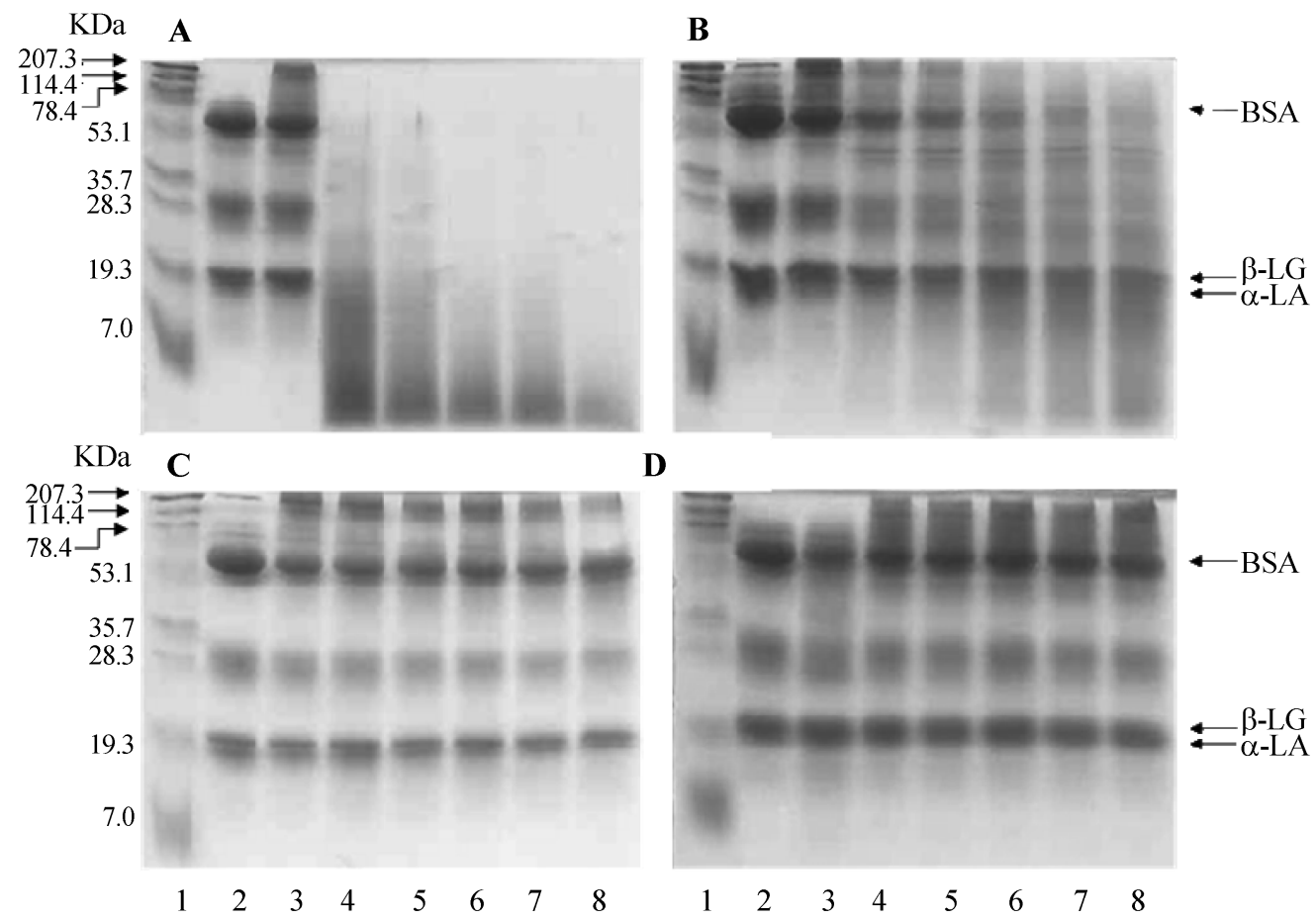

Fig. 2. SDS-PAGE patterns of heated colostral whey hydrolyzed at $50^{\circ} \mathrm{C}$ with alcalase (A), pepsin (B), papain (C), and trypsin (D). 1: Standard board range marker (Bio-rad, USA), 2: Colostral whey, and 3: Heated colostral whey. Lanes 4-8 are different incubation times of $15,30,60,90$, and 120 min, respectively.

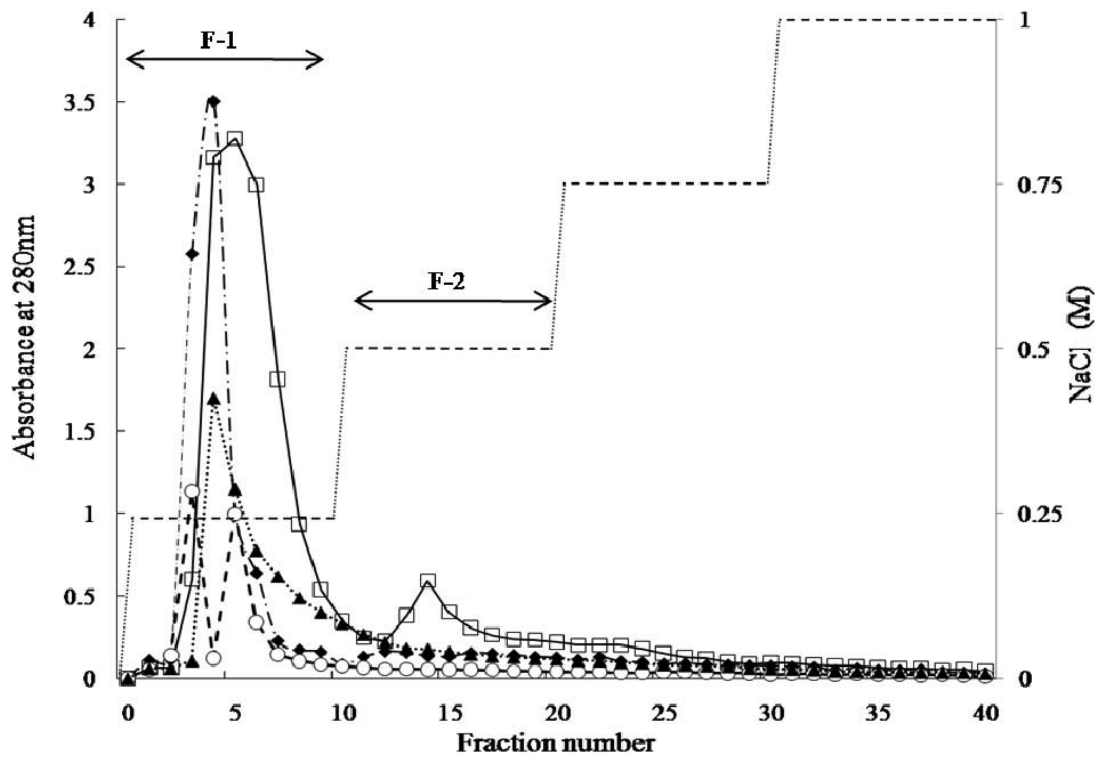

Fig. 3. Ion-exchange chromatograms of heated colostral whey hydrolysate by alcalase $(\square)$, pepsin $(\diamond)$, typsin $(\triangle)$, and papain $(O)$. Their hydrolysates dissolved in $20 \mathrm{mM}$ Tris- $\mathrm{HCl}$ buffer ( $\mathrm{pH}$ 7.8) were applied to the column. The column packed with DEAEcellulose was washed with the same buffer, and then eluted with a step gradient of $\mathrm{NaCl}$ as indicated. The flow rate was $3 \mathrm{~mL} /$ min, fraction volume was $30 \mathrm{~mL}$ per tube, and elution was monitored at $280 \mathrm{~nm}$. 
(Fig. 2D) failed to hydrolyze bovine serum albumin, $\beta$ LG, and $\alpha$-LA after 120 min of incubation.

\section{Separation of iron-binding protein}

Ion-exchange chromatograms of heated colostral whey hydrolysate by alcalase, pepsin, trypsin, and papain are shown in Fig. 3. Fractions 1 (F-1) and 2 (F-2) were eluted from hydrolysates at the 0.25 and $0.5 \mathrm{M} \mathrm{NaCl}$ chromatographic step gradients, respectively. The RP-HPLC chromatogram patterns of each F-1 obtained from iron-exchange chromatography shown in Fig. 4. Many new peaks of shorter length of peptides appeared on the chromatograms of enzymatic hydrolysates of heated colostral whey, which indicates degradation of whey protein into new shorter peptides. Heated colostral whey hydrolysates derived with alcalase (Fig. 4A) and pepsin (Fig. 4B) produced greater numbers of shorter peaks than those derived with papain and trypsin. However, the chromatograms of hydrolysates by papain (Fig. 4C) and trypsin (Fig. 4D) showed that $\beta$-LG still survived these enzyme treatments.
Iron contents of fractions (F-1 and F-2) obtained from ion-exchange chromatography of heated colostral whey hydrolysate are show in Fig. 5. The highest iron contents were observed in F-1 that was derived with alcalase (28.94 $\mathrm{mg} / \mathrm{L})$. This value was much higher than that $(0.21 \mathrm{mg} / \mathrm{L})$ observed for alcalase F-1 prepared from whey protein concentrate (Kim et al., 2007). Iron contents of trypsin F1, pepsin F-1, and papain F-1 were 7.39, 7.04, and 3.27 $\mathrm{mg} / \mathrm{L}$, respectively.

\section{Amino acid composition}

The amino acid compositions of heated colostral whey and the F-1 eluted by ion-exchange chromatography of the alcalase hydrolysate are shown in Table 1 . The heated colostral whey contained greater amount of Ala (16.09\%) and Glu (14.85\%) and lower amount of Ser (4.86\%). However, Kim et al. (2007) reported that whey protein concentrate had higher amount of Glu and Leu, and lower amount of Ala. This difference can be due to higher proportion of immunoglobulins in heated clolostral whey.

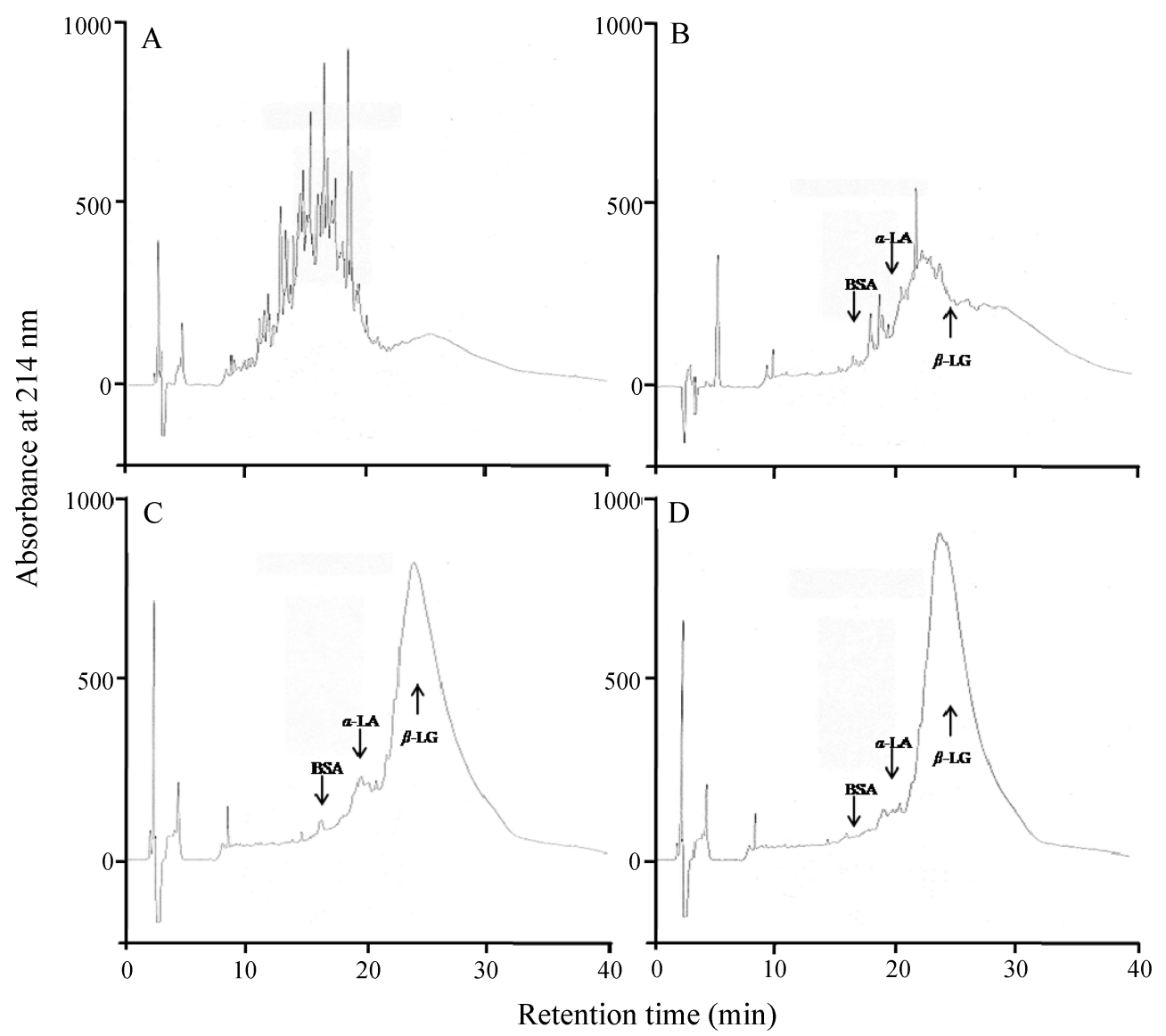

Fig. 4. RP-HPLC chromatogram of fraction 1 (F-1) isolated by ion-exchange chromatography from heated colostral whey hydrolysates treated with alcalase (A), pepsin (B), papain (C), and trypsin (D). The column was equilibrated with solvent A $\left(0.1 \%\right.$ TFA in $\left.\mathrm{H}_{2} \mathrm{O}\right)$ and eluted with a linear gradient of solvent $\mathrm{B}(0.1 \%$ TFA in acetonitrile). The flow rate was $1 \mathrm{~mL} / \mathrm{min}$, injection volume was $10 \mu \mathrm{L}$, and detection was at $214 \mathrm{~nm}$. 


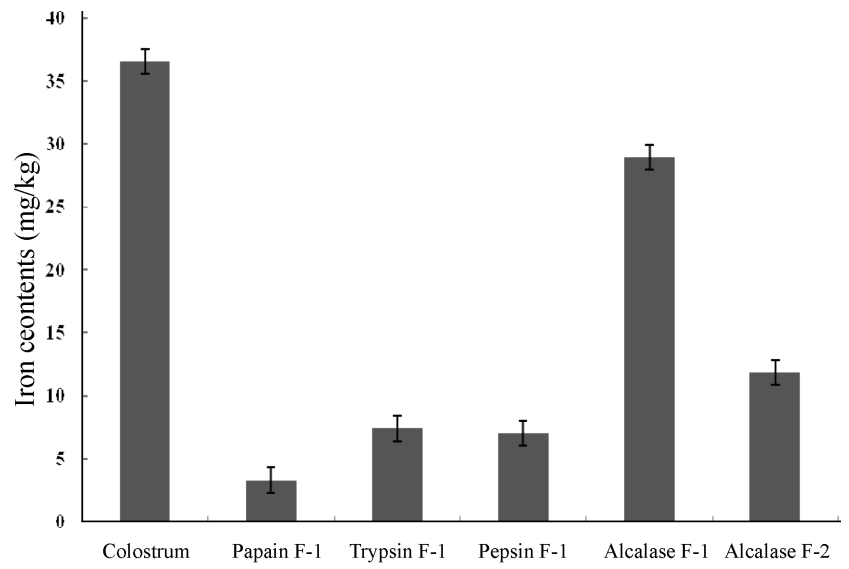

Fig. 5. Mean $( \pm \mathrm{SD})$ iron contents $(\mathrm{mg} / \mathrm{kg})$ of heated colostral whey and fractions from respective enzymatic treatments of heated colostral whey. Each suspension was dissolved in de-ionized water $(1 \%$ protein basis and $\mathrm{pH}$ 5.0). Iron-binding protein/peptides were precipitated by the addition of $0.1 \%(\mathrm{w} / \mathrm{v}) \mathrm{FeSO}_{4}$, and incubation at $37^{\circ} \mathrm{C}$ for $1 \mathrm{~h}$. The iron contents were determined using ICP (Inductively Coupled Plasma Spectrometer, ICP-OES, Varian, USA).

Table 1. Amino acid composition of heated colostral whey and fraction 1 (F-1) eluted from ion-exchange chromatog-raphy of alcalase hydrolysate

\begin{tabular}{|c|c|c|}
\hline Amino acids & $\begin{array}{c}\text { Colostral whey } \\
\text { protein }(\%)\end{array}$ & $\begin{array}{c}\text { Alcalase F-1 } \\
(\%)\end{array}$ \\
\hline Aspartic acid (Asp) & $9.50 \pm 0.1^{1)}$ & $8.02 \pm 0.08$ \\
\hline Threonine (Thr) & $6.07 \pm 0.08$ & $15.45 \pm 0.09$ \\
\hline Serine (Ser) & $4.86 \pm 0.06$ & $10.39 \pm 0.07$ \\
\hline Glutamic acid (Glu) & $14.85 \pm 0.1$ & $14.12 \pm 0.15$ \\
\hline Proline (Pro) & $1.15 \pm 0.02$ & $2.44 \pm 0.04$ \\
\hline Glycine (Gly) & $4.25 \pm 0.01$ & $6.31 \pm 0.16$ \\
\hline Alanine (Ala) & $16.09 \pm 0.09$ & $5.89 \pm 0.11$ \\
\hline Valine (Val) & $5.90 \pm 0.07$ & $5.51 \pm 0.06$ \\
\hline Cysteine (Sys) & $2.31 \pm 0.06$ & $1.46 \pm 0.08$ \\
\hline Methionine (Met) & $3.86 \pm 0.11$ & $4.11 \pm 0.15$ \\
\hline Isoleucine (Ile) & $4.47 \pm 0.11$ & $4.46 \pm 0.18$ \\
\hline Leucine (Leu) & $5.61 \pm 0.09$ & $8.16 \pm 0.07$ \\
\hline Tyrosine (Tyr) & $2.64 \pm 0.04$ & $2.16 \pm 0.04$ \\
\hline Phenylalanine (Phe) & $3.38 \pm 0.04$ & $2.06 \pm 0.08$ \\
\hline Lysine (Lys) & $3.91 \pm 0.03$ & $4.15 \pm 0.1$ \\
\hline Histidine (His) & $1.43 \pm 0.01$ & $2.89 \pm 0.1$ \\
\hline Arginine (Arg) & $9.73 \pm 0.07$ & $2.41 \pm 0.05$ \\
\hline Total mol. ratio & 100.00 & 100.00 \\
\hline
\end{tabular}

${ }^{1)}$ Values are means \pm SE.

Immunoglobulins account for about $50 \%$ of the total amount of colostrum proteins, and about $90 \%$ of immunoglobulin is $\operatorname{IgG}_{1}$ (Georgiev, 2008). Ser (13.57\%) is highest amounts of amino acid of all amino acids in $\mathrm{IgG}_{1}$, and Ala and Glu constitute 5.76 and $8.20 \%$, respectively (Larson, 1992). Therefore, lower Ser content found in our study could be due to lower content of Ser in $\alpha$-LA and $\beta$-LG. Higher proportion of Glu in $\operatorname{IgG}_{1}, \alpha$-LA, and $\beta$-LG is responsible for higher content of Glu in our heated colostral whey. Alcalase F-1 had high percentage of Thr (15.45\%), Glu (14.12\%), and Ser (10.39\%), whereas Kim et al. (2007) reported whey protein concentrate had high percentage of Ala, Phe, and Lys.

\section{References}

1. Adler-Nissen, J. (1979) Determination of the degree of hydrolysis of food protein hydrolysates by trinitrobenzenesulfonic acid. J. Agric. Food Chem. 27, 1256-1262.

2. Bradford, M. M. (1976) A rapid and sensitive method for the quantitation of microgram quantities of protein utilizing the principle of protein-dye binding. Anal. Biochem. 72, 248-254.

3. Foley, J. A. and Otterby, D. E. (1978) Availability, storage, treatment, composition, and feeding value of surplus colostrum: A review. J. Dairy Sci. 61, 1033-1060.

4. Fox, P. F. (1989) The milk protein system. In P. F. Fox (Ed.), Developments in dairy chemistry, London, UK: Elsevier Applied Science, Vol. 4, pp. 1-53.

5. Georgiev, P. (2008) Differneces in chemical composition between cow colostrums and milk. Bulgarian J. V. Med. 11, 312.

6. Kim, S. B., Seo, I. S., Khan, M. A., Ki, K. S., Nam, M. S., and Kim, H. S. (2007) Separation of iron-binding protein whey through enzymatic hydrolysis. Int. Dairy J. 17, 625-631.

7. Larson, B. (1992) Immunoglobulins of the mammary secretions. In: Advanced dairy chemistry.p Fox. P. F. (ed). Elsevier Applied Science, London, UK, pp. 231-254.

8. Liang, J., Han, B., Nout, M. J. R., and Hamer, R. J. (2009) Effect of soaking and phytase treatment on phytic acid, calcium, iron and zinc in rice fractions. Food Chem. 115, 789794.

9. Liang, J., Han, B., Nout, M. J. R., and Hamer, R. J. (2008) Effect of soaking, germination and fermentation on phytic acid, total and in vitro soluble zinc in brown rice. Food Chem. 110, 821-828.

10. Moore, S., Spackman, D. H., and Stein, W. H. (1958) Automatic recording apparatus for use in the chromatography of amino acids. Fed. Am. Soc. Exp. Biol. 17, 1107-1115.

11. Pintado, M. E., Pintado, A. E., and Malcata, F. X. (1999) Controlled whey protein hydrolysis using two alternative proteases. J. Food Eng. 42, 1-13.

12. Playford, R. J., Macdonald, C. E., and Johnson, W. S. (2000) Colostrum and milk-derived peptide growth factors for the treatment of gastrointestinal disorders. Am. J. Clin. Nutr. 72, 514.

13. Rebeca, B. D., Pena-Vera, M. T., and Diaz-Castaneda, M. (1991) Production of fish protein hydrolysates with bacterial proteases: Yield and nutritional value. J. Food Sci. 56, 309314.

14. Rose, D., Davies, D. T., and Yaguchi, M. (1969) Quantitative determination of the major components of casein mixture by 
column chromatography on DEAE-cellulose. J. Dairy Sci. 52, 8-11.

15. SAS (2002) SAS User's Guide, Version 6.02. SAS Institute Inc., NC.

16. Symth, M. and Fitz-Gerald, R. J. (1998) Relationship between some characteristics of WPC hydrolysates and the enzyme complement in commercially available proteinase preparations. Int. Dairy J. 8, 819-827.
17. Sukan, G. and Andrews, A. T. (1982) Application of the plastein reaction to caseins and to skim milk powder. I. Protein hydrolysis and plastein formation. J. Dairy Res. 49, 265-278.

18. WHO (2001) Iron deficiency anemia: Assessment, prevention and control. Geneva, Switzerland: World Health Organisation, pp. 1-22.

(Received 2010.8.25/Revised 2010.11.22/Accepted 2010.11.24) 